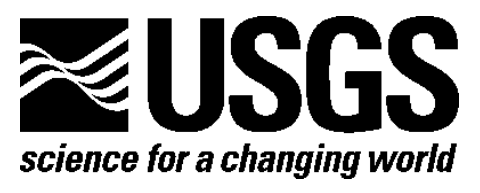

Study Number: AEH-11-RASFRM-01; INAD Number: 011-365

\title{
Literature Review of the Potential Effects of Formalin on Nitrogen Oxidation Efficiency of the Biofilters of Recirculating Aquaculture Systems (RAS) for Freshwater Finfish
}

By Kim T. Fredricks

Open-File Report 2015-1097

U.S. Department of the Interior

U.S. Geological Survey 


\title{
U.S. Department of the Interior SALLY JEWELL, Secretary
}

\section{U.S. Geological Survey Suzette M. Kimball, Acting Director}

\author{
U.S. Geological Survey, Reston, Virginia: 2015
}

For more information on the USGS-the Federal source for science about the Earth, its natural and living resources, natural hazards, and the environment-visit http://www.usgs.gov or call 1-888-ASK-USGS (1-888-275-8747)

For an overview of USGS information products, including maps, imagery, and publications, visit http://www.usgs.gov/pubprod

To order this and other USGS information products, visit http://store.usgs.gov

Any use of trade, firm, or product names is for descriptive purposes only and does not imply endorsement by the U.S. Government.

Although this information product, for the most part, is in the public domain, it also may contain copyrighted materials as noted in the text. Permission to reproduce copyrighted items must be secured from the copyright owner.

\section{Suggested citation:}

Fredricks, K.T., 2015, Literature review of the potential effects of formalin on nitrogen oxidation efficiency of the biofilters of recirculating aquaculture systems (RAS) for freshwater finfish: U.S. Geological Survey Open-File Report 2015-1097, 17 p., http://dx.doi.org/10.3133/ofr20151097. 


\section{Acknowledgments}

This literature review was funded through an interagency agreement with the U.S. Geological Survey Upper Midwest Environmental Sciences Center (UMESC) and the U.S. Food and Drug Administration (FDA)

(number 224-12-7017) in response to the FDA Funding Opportunity Announcement RFA-FD-12-003. The author also acknowledges Lisa Hein, UMESC librarian, for her work in conducting the searches and obtaining the papers. 



\section{Contents}

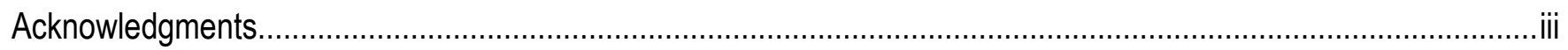

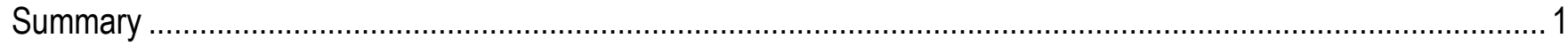

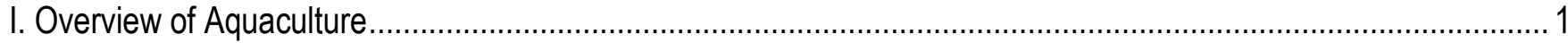

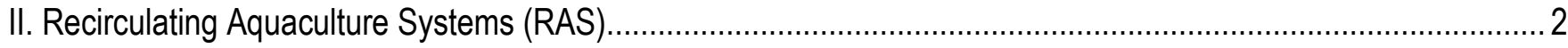

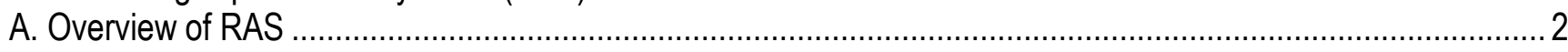

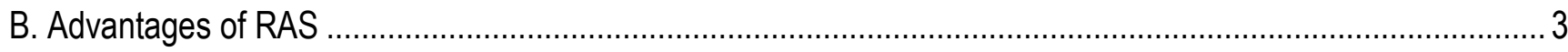

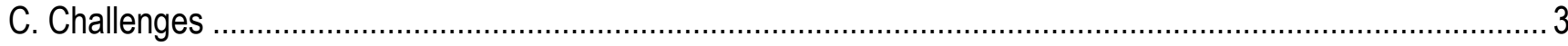

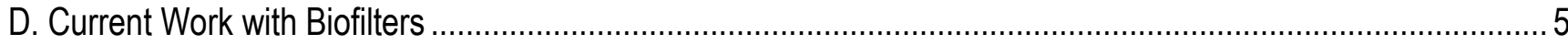

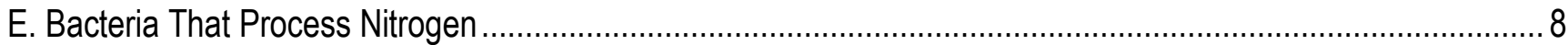

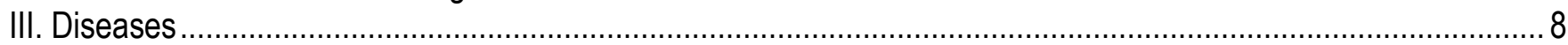

IV. Use of Formalin in RAS

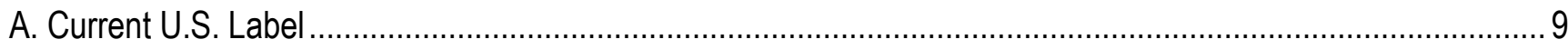

B. Application of Formalin in RAS-Effects on Biofilter Bacteria .................................................................. 9

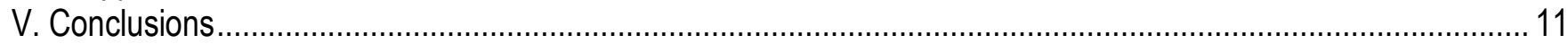

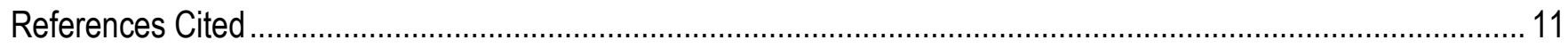

Tables

Table 1. Summary of papers that tested the effects of formaldehyde on recirculating aquaculture systems..... 11 


\section{Conversion Factors}

International System of Units to Inch/Pound

\begin{tabular}{|c|c|c|}
\hline Multiply & By & To obtain \\
\hline \multicolumn{3}{|c|}{ Area } \\
\hline square meter $\left(\mathrm{m}^{2}\right)$ & 10.7639 & square foot $\left(\mathrm{ft}^{2}\right)$ \\
\hline square meter $\left(\mathrm{m}^{2}\right)$ & 1.19599 & square yard $\left(\mathrm{yd}^{2}\right)$ \\
\hline \multicolumn{3}{|c|}{ Length } \\
\hline Micrometer $(\mu \mathrm{m})$ & $3.937 \times 10^{-5}$ & inch (in.) \\
\hline \multicolumn{3}{|c|}{ Volume } \\
\hline liter (L) & 33.814 & ounce, fluid (fl. oz) \\
\hline liter (L) & 2.11338 & pint (pt) \\
\hline liter (L) & 1.05669 & quart (qt) \\
\hline liter (L) & 0.264172 & gallon (gal) \\
\hline cubic meter $\left(\mathrm{m}^{3}\right)$ & 264.172 & gallon (gal) \\
\hline \multicolumn{3}{|c|}{ Flow rate } \\
\hline centimeters per second $(\mathrm{cm} / \mathrm{sec})$ & 0.0328 & foot per second (ft/sec) \\
\hline \multicolumn{3}{|c|}{ Mass } \\
\hline milligram (mg) & $3.5274 \times 10^{-5}$ & ounce, avoirdupois (oz) \\
\hline kilogram (kg) & 2.20462 & pound, avoirdupois (lb) \\
\hline metric ton (tonnes) & 0.0984207 & pound, avoirdupois (lb) \\
\hline metric ton (tonnes) & 1.016 & ton, long $(2,240 \mathrm{lb})$ \\
\hline \multicolumn{3}{|c|}{ Density } \\
\hline kilogram per cubic meter $\left(\mathrm{kg} / \mathrm{m}^{3}\right)$ & 0.062428 & pound per cubic foot $\left(\mathrm{lb} / \mathrm{ft}^{3}\right)$ \\
\hline kilogram per cubic meter $\left(\mathrm{kg} / \mathrm{m}^{3}\right)$ & 0.008345 & pound per US gallon (lb/gal) \\
\hline kilogram per square meter $\left(\mathrm{kg} / \mathrm{m}^{2}\right)$ & 0.20482 & pound per square foot $\left(\mathrm{lb} / \mathrm{ft}^{2}\right)$ \\
\hline
\end{tabular}

Temperature in degrees Celsius $\left({ }^{\circ} \mathrm{C}\right)$ may be converted to degrees Fahrenheit $\left({ }^{\circ} \mathrm{F}\right)$ as ${ }^{\circ} \mathrm{F}=\left(1.8 \times{ }^{\circ} \mathrm{C}\right)+32$.

\section{Supplemental Information}

Concentrations of chemical constituents in water are given in milligrams per liter (mg/L). 


$\begin{array}{ll}\text { Abbreviations } \\ \mathrm{CaCO}_{3} & \text { calcium carbonate } \\ \mathrm{C} / \mathrm{N} & \text { carbon nitrogen ratio } \\ \mathrm{CO}_{2} & \text { carbon dioxide } \\ \mathrm{DO} & \text { dissolved oxygen } \\ \mathrm{FDA} & \text { U.S. Food and Drug Administration } \\ \mathrm{NH}_{3}-\mathrm{N} & \text { un-ionized ammonia-nitrogen } \\ \mathrm{NO}_{3}-\mathrm{N} & \text { nitrate-nitrogen } \\ \mathrm{PAA} & \text { peracetic acid } \\ \text { ppm } & \text { parts per million } \\ \mathrm{PVC} & \text { polyvinyl chloride } \\ \mathrm{RAS} & \text { recirculating aquaculture systems } \\ \text { rRNA } & \text { ribosomal ribonucleic acid } \\ \text { TAN } & \text { total ammonia nitrogen } \\ \text { UMESC } & \text { Upper Midwest Environmental Sciences Center } \\ \text { USGS } & \text { U.S. Geological Survey } \\ \text { USP } & \text { United States Pharmacopeia }\end{array}$





\title{
Literature Review of the Potential Effects of Formalin on Nitrogen Oxidation Efficiency of the Biofilters of Recirculating Aquaculture Systems (RAS) for Freshwater Finfish
}

\author{
By Kim T. Fredricks
}

\section{Summary}

A comprehensive literature review was done for the effects of formalin on biofilter function in recirculating aquaculture systems (RAS) using these databases: ISI/Web of Knowledge, Scopus, and Pubmed. Inclusion and exclusion criteria were developed as the literature review was conducted. The initial search produced 5,682 potential citations. Once the literature search was complete, these 5,682 titles were screened for applicable papers using the inclusion and exclusion criteria. If the title contained any of the inclusion terms, it was retained. Titles of the remaining papers were then screened for exclusion terms. If the title contained one or more of the exclusion terms, it was eliminated from further consideration. This refined search produced 1,287 papers.

After the initial screening, the remaining 1,287 papers underwent a second screening. Titles and abstracts (when available) were again read to verify that the topic of the paper was related to RAS. During the second screening, a second person verified that the papers proposed for elimination were not related to RAS. A combined reference list of the 443 remaining papers was created and submitted to the U.S. Geological Survey (USGS) Upper Midwest Environmental Sciences Center (UMESC) librarian to obtain the actual papers; electronic copies of those citations were obtained and reviewed. The UMESC librarian also would receive weekly updates from Scopus (a bibliographic database containing abstracts and citations for academic journal articles) using the search terms. Any resulting papers from those updates also were screened using the inclusion criteria, and any relevant papers were requested. From those, 82 were cited in the literature review. An additional 10 references were obtained from weekly updates or reference mining other sources and were incorporated into the final literature review.

\section{Overview of Aquaculture}

Aquaculture may be defined as cultivation of saleable aquatic products under controlled conditions using the highest stocking density possible, the highest quality feeds, and active waterquality management (Ebeling and others, 2006). Aquaculture accounts for about 50 percent of the world's food fish (Food and Agriculture Organization of the United Nations, 2014), particularly in Asia and developing countries (Håstein and others, 2006; Crab and others, 2007). By 2030, an estimated 62 percent of fish for human consumption will come from aquaculture (Food and Agriculture Organization of the United Nations, 2014). In 2004, 17.3 million tonnes of carp (Cyprinus carpio), 1.2 million tonnes of tilapia (Tilapia spp.), 1.1 million tonnes of salmon (Oncorhynchus sp.), and 
0.5 million tonnes each of rainbow trout (Oncorhynchus mykiss) and shrimp were produced using aquaculture methods (Håstein and others, 2006). Salmon farming is the main economic activity in Chile, valued at about US\$224.4 million (Bravo and others, 2013). Sustained and enhanced productivity are major goals of aquaculture, and current technologies have led to the expansion of aquaculture production (Panigrahi and Azad, 2007).

Aquaculture systems can be classified as one of three types: extensive systems (which require little daily care by a fish culturist), intensive systems (in which fish survival depends completely on the intervention by a fish culturist), and intensive recirculating systems (Ebeling and others, 2006). RAS, in particular, are intensive because of the additional need to manage water quality in addition to feeding. This brings on unique challenges as well as benefits. This review will focus on recirculation systems, particularly those that use freshwater.

\section{Recirculating Aquaculture Systems (RAS)}

\section{A. Overview of RAS}

RAS are controlled environments used to intensively rear fish and other aquatic organisms in ecologically sustainable ways (Summerfelt and others, 2001; Wik and others, 2009). RAS technology is designed for intensive fish farming where water availability is limited (Avnimelech, 2006; Ebeling and others, 2006; Badiola and others, 2012) or where biosecurity concerns limit water intake (Avnimelech, 2006). Intensive recirculating systems recycle 90 to 99 percent of the water used to grow fish or other aquatic organisms (Summerfelt and others, 2001; Ebeling and others, 2006; Park and others, 2008; Badiola and others, 2012). With greater operator control over water quality, an operator can optimize growth conditions for the species being reared (Badiola and others, 2012; Carrera and others, 2013). Maintaining water quality for growout systems may provide greater economic output for the producer. Critical water-quality variables in RAS include dissolved oxygen, carbon dioxide, ammonia, nitrite, nitrate, pheromones, endocrine disrupters that may affect fish maturation, and other toxic chemicals that may leach from rubber or plastics used in building the RAS (Colt and others, 2006). RAS typically have a unit for growing fish, a mechanical filter to remove larger particles before biofiltration, an aerobic biological nitrification area to remove potentially toxic nitrogenous compounds, and sometimes an anaerobic denitrification filter (Barbu and others, 2008).

Biofilters are used to help control the accumulation of ammonia-nitrogen in RAS. The main driver of water quality in RAS is the feeding rate. As fish metabolize protein in feed, they release ammonia as a waste product. Oxygen levels within the culture tank are reduced as a result of bacterial metabolism of nitrogenous compounds $\left(\mathrm{NH}_{4}^{+}+\mathrm{O}_{2} \rightarrow \mathrm{NO}_{3}^{-}\right)$. Oxygenation of culture tanks had a significant impact on reducing the ammonia concentration that reached the biofilters (Caraman and others, 2010). Nitrifying bacteria are well known for their ability to secrete and embed in a lipopolysaccharide matrix that helps create a stable biofilm (Hagopian and Riley, 1998). Fast growing heterotrophic bacteria form the outer layers of biofilms where they can use available oxygen. Oxygen use by heterotrophic bacteria, however, can limit the nitrification processes because oxygen is required for ammonia oxidation (Chen and others, 2006). In one study, nitrification was limited to the top 50 micrometers $(\mu \mathrm{m})$ of the biofilm (Schramm and others, 1996). Slow growing nitrifying bacteria are protected under the outer layer (Michaud and others, 2006).

Attached biofilms on biofilter material are advantageous in that there is increased efficiency from a large surface area and stability that reduces the chance of biofilms being washed out. Nitrosomanas form dense clusters in the upper part of the biofilm and Nitrobacter cluster around the Nitrosomanas clusters, though less densely. Nitrifiers in the deeper anoxic layers are relatively 
uncommon (Schramm and others, 1996). Nitrification processes also can be inhibited by heterotrophic processes when organic carbon is present. Nitrification decreased about 70 percent due to heterotrophic processes when organic carbon was present in RAS in a carbon to nitrogen $(\mathrm{C} / \mathrm{N})$ ratio of 1 or more (Zhu and Chen, 2001). In production, biofilters may operate under an organic load that is high enough to inhibit the nitrification efficiency so it is beneficial for RAS operators to remove organic matter to maximize nitrification processes. (A more complete overview of RAS can be found in the Engineering Assessment by Holder Timmons Engineering and Julie Bebak, written commun., 2014).

\section{B. Advantages of RAS}

There are several advantages to RAS. Recirculation of water helps reduce use. Compared with a flow-through system, use of a rotating biological contactor in a RAS unit reduced water consumption by 90 percent with no negative effects on specific growth or condition factors of rainbow trout (d'Orbcastel and others, 2009a; Marin and others, 2011). Within the effluent of a non-RAS facility are high levels of phosphorus, carbon, and nitrogen from feed waste, which can have a negative environmental impact. Food conversion can be increased in RAS, thereby reducing the potential environmental impact. The lower water-exchange rates in RAS also allow for temperature control, which can lead to year-round production (Gutierrez-Wing and Malone, 2006; Lyssenko and Wheaton, 2006) and help reduce energy costs associated with maintaining a particular temperature (Summerfelt and others, 2001; Avnimelech, 2006; Gutierrez-Wing and Malone, 2006). RAS also allow for greater biosecurity and independence in location of production facilities (Summerfelt and others, 2001; Cancino-Madariaga and others, 2011). Hybrid striped bass, for example, have been reared in the deserts of California (Gutierrez-Wing and Malone, 2006). Lastly, RAS allow for higher fish-production rates and a higher density of fish per rearing tank (Lyssenko and Wheaton, 2006; Good and others, 2009; Gullian-Klanian and ArámburuAdame, 2013). For example, in one study, freshwater eel (Abguilla japonica) were raised at a density of 2.6 percent (compared to 0.6 percent traditionally) in a nearly closed system that only replaced water lost to evaporation (Suzuki and others, 2003).

\section{Challenges}

A significant challenge with RAS is that, unlike flow-through systems, nitrogenous and organicwaste products accumulate in the rearing tank. RAS thus require biofilters to remove the nitrogenous wastes and settling tanks to help remove organic wastes. If fish are stocked before the biofilter is fully functional, fish can develop methemoglobinemia (Svobodová and others, 2005). Establishing biofilters is a challenge because the bacteria that oxidize ammonia and nitrite to less toxic nitrate are slower growing. Allowing a natural population of bacteria to colonize a biofilter can take 4 to 8 weeks (Kuhn and others, 2010). One reason that biofilters take time to establish is that the heterotrophic bacteria can out-compete the nitrifying bacteria for space and oxygen because of their faster growth rates (CancinoMadariaga and others, 2011; Michaud and others, 2006; Brambilla and others, 2008; Blancheton and others, 2013). Using a starter culture can significantly decrease the time needed to establish a biofilter (Gross and others, 2003; Kuhn and others, 2010).

Other technologies are being investigated as a means to remove ammonia from RAS that do not have the same challenges as establishing a biofilter. For example, reverse osmosis membranes also may help with ammonia removal in RAS (Cancino-Madariaga and others, 2011). Ion-exchange resin also can help remove ammonia from RAS. These resins are cheaper to use, require a smaller volume than a typical biofilter, do not require a long start-up, are not temperature sensitive, and can be turned on and off at will. Additionally, the resins convert ammonia directly to nitrogen gas (Gendel and Lahav, 2013). 
A second challenge with RAS is that the higher rearing density may stress fish, reducing their immune function, which may then provide greater opportunity for pathogens to infect fish. If a pathogenic organism is introduced into the system, either from addition of new stock or replacement water, it may persist in the biofilms within the system (King and others, 2008; Jacobs and Chenia, 2011). This can result in recurring fish mortality and economic losses to the facility. Many of the pathogens are opportunistic and cause disease only if the fish are compromised or if their environment is suboptimal. The organic peroxide peracetic acid (PAA) had the greatest effect on inhibiting growth of pathogenic bacteria in biofilms of RAS (King and others, 2008). However, there is always a concern that use of disinfectants may impair the nitrifying bacteria in the biofilters, resulting in accumulation of ammonia or nitrite, which is toxic to fish (Summerfelt and others, 2001; Pedersen and others, 2009).

A third challenge is off-flavors in fish that can result in economic loss for the producers. These off-flavors are produced by bacteria Nocardia cummidelens, N. fluminea, Streptomyces roseoflavus, Streptomyces luridiscabiei, and Streptomyces $c f$. albidoflavus that were isolated from RAS biofilters (Guttman and van Rijn, 2008; Schrader and Summerfelt, 2010; Auffret and others, 2013) and heat exchangers (Schrader and Summerfelt, 2010).

Biofilter operation and solids management were identified as main issues in RAS in a survey conducted in Europe (Badiola and others, 2012). Integration of the current technology to manage biofilters and solids within commercial scale RAS is a challenge. One reason for this is that much of the research has been at laboratory scale, which does not translate well to commercial-scale operations (Badiola and others, 2012). Dissolved organic carbon from feed waste or improper mechanical filtration can reduce nitrification because the heterotrophic bacteria feed on the carbon and overgrow the autotrophic nitrifying bacteria within the biofilms (Guerdat and others, 2011).

Other challenges with aquaculture, both freshwater and marine, include food-safety concerns. Rearing fish in crowded tanks can increase the risk of disease transmission, and may require the use of antibiotics or other therapeutic agents to prevent loss of the crop. For example, Streptocossus iniae may cause chronic septicemia in fish. It is commonly isolated from cultured species including rainbow trout, tilapia, channel catfish (Ictalurus nebulosus), and Japanese flounder (Paralichthys olivenceus) (Håstein and others, 2006). Antibiotic use, particularly in countries where regulation is not as stringent as it is in the U.S., is a concern because it can lead to the development of resistant bacteria. Those resistance determinants may then be transferred to zoonotic pathogens which could impact humans or other commercially important animals. For example, molecular evidence exists that Aeromanas can transmit determinants for resistance to antibiotics with the human pathogen Escherichia coli (Cabello, 2006). Horizontal gene transfer of bacterial resistance has been shown from aquaculture to humans (Heuer and others, 2009). Antimicrobial use in developed countries is more restricted to try to prevent resistance in human pathogens; however, in other countries, their use is not as restricted. In 2007, for example, Canada used 0.175 kilograms $(\mathrm{kg})$ of antimicrobials/metric ton of salmon produced whereas Chile used $1.4 \mathrm{~kg}$ per metric ton of salmon produced (Cabello and others, 2013). Other countries are reducing their use of antibiotics to reduce the potential for resistance. Norway reduced antibiotic use by 37 percent from 1992 to 1996 and by 96 percent in fish that were farmed, even though biomass of farmed fish increased by 100 percent (Grave and others, 1999).

Aquaculture produces substantial nutrient and organic matter that must be treated. Nutrients can increase phytoplankton (i.e., eutrophication) and potentially decrease water quality. Excess organic matter can limit dissolved oxygen, which could negatively affect other aquatic life in the area near the discharge of wastewater (Ghaly and others, 2005). Higher levels of nitrogen and phosphorus released with wastewater can accelerate eutrophication (Hussenot, 2003). Mats created from waste feed and discharged fecal matter may decrease benthic biodiversity and increase biological oxygen demand 
(Droppo and others, 2007). Some of these environmental concerns can be mitigated. For example, phytotreatment can be used to help remove nitrogen and phosphorus from water before it is discharged (Porrello and others, 2003). The plants that are produced can be used as feed, which may provide another source of income. Rye, barley, and oats were found to be the best plants at removing nitrogen and phosphorus in one study (Ghaly and others, 2005).

Lastly, investment costs are higher with RAS compared to flow-through systems. In 1998, it cost about US $\$ 0.90$ per pound (lb) of annual production in a pond system compared to US $\$ 1.00-4.00$ for RAS (Gutierrez-Wing and Malone, 2006). The payback period also is longer than other systems, on average about 8 years (Badiola and others, 2012). Overall energy costs are typically higher with RAS compared to flow-through as well (Singh and Marsh, 1996; d'Orbcastel and others, 2009b).

\section{Current Work with Biofilters}

With increased biomass in RAS, water quality often becomes a limiting factor for growth, mostly due to increased ammonia and nitrites produced as fish metabolize protein in feed (Hagopian and Riley, 1998). Water quality can be controlled by replacement, which often requires high exchange rates, or by recycling water through a biological filter (Avnimelech, 2006). Biological filters, or biofilters, are an important component of RAS and are used to reduce total ammonia (ionized and un-ionized ammonia) through nitrification processes that oxidize ammonia to nitrite then nitrate. Biofilters can be made of a variety of materials but are often divided into two main categories. Fixed film biofilters have media for microorganism attachment and growth whereas suspended growth biofilters maintain the microorganisms in suspension. Suspended growth biofilters require more management and are not commonly used in RAS (Gutierrez-Wing and Malone, 2006). Effective biofilters have high populations of nitrifying bacteria that help reduce water required for tank exchanges in RAS (Guerdat and others, 2010). However, if organic load in the RAS is high, some heterotrophic bacteria can migrate to the biofilter and impair function of the nitrifying bacteria (Barbu, 2012). Carbon dioxide $\left(\mathrm{CO}_{2}\right)$ is produced by biofilters through respiration of the nitrifying bacteria. Summerfelt and Sharrer (2004) estimated that the biofilter accounted for 37 percent of the total $\mathrm{CO}_{2}$ produced in a salmonid RAS and suggested that a $\mathrm{CO}_{2}$ stripping unit be placed immediately after the biofilter, where $\mathrm{CO}_{2}$ is at its highest level, to minimize the $\mathrm{CO}_{2}$ fish are exposed to as the water recirculates. Currently (2015), there is no standardized method to evaluate biofilter performance, though several authors have suggested the need for developing standards for the industry to help plan for media and volume of media used in RAS (Colt and others, 2006; Malone and Pfeiffer, 2006).

Fixed film biofilters used in recirculating systems include rotating biological contractors (Brazil, 2006; Marin and others, 2011), trickling filters (Kamstra and others, 1998; Eding and others, 2006; Barbu, 2012), sequencing batch reactors (Fontenot and others, 2007; De Schryver and Verstraete, 2009; Luo and others, 2013), and fluidized bed biofilters (Skjølstrup and others, 1998; Malone and Beecher, 2000; Timmons and others, 2006; Weaver, 2006; Davidson and others, 2008). Various media and flow rates have been studied, and one study indicated that media characteristics may be more important than flow rates at affecting the efficacy of the filter (Yang and others, 2001). The filter material should have a surface capable of developing biofilms and capturing organic solids (Yang and others, 2001). Media size and surface area often influences maximal feed load, which affects the amount of total ammonia nitrogen (TAN) that can be removed (Summerfelt, 2006; Pfeiffer and Wills, 2011). Media can vary between commercially available media (Pfeiffer and Wills, 2011) to something as simple as polyvinyl chloride (PVC) shavings (Prinsloo and others, 1999). Other low cost materials that have been used in effective biofilters include lava stones and oyster shells (Ogunlela and Ogunlana, 2011), Styrofoam beads (Peng and others, 2003), wood chips and wheat straw (Saliling and others, 2007), polystyrene 
microbeads (Timmons and others, 2006), and scrub pads and plastic hair rollers (Al-Hafedh and others, 2003). More surface area does not necessarily mean more TAN removal. In one study, commercially available Siporax glass beads with a water contact area of 32,000 square meters $\left(\mathrm{m}^{2}\right)$ were only 93 percent efficient at converting ammonia nitrogen $\left(\mathrm{NH}_{3}-\mathrm{N}\right)$ to nitrate nitrogen $\left(\mathrm{NO}_{3}-\mathrm{N}\right)$, while the PVC shavings with a water contact area of $1,220 \mathrm{~m}^{2}$ were 96 percent efficient (Prinsloo and others, 1999).

In rotating biological contractors, media (typically molded disks with a high surface area) is attached to a central horizontal shaft. The rotation of the filter partly submerges some of the media and rotation allows for shearing of excess biofilm growth (Brazil, 2006). Trickling biofilters, on the other hand, use a fixed media through which pre-filtered water is trickled down the height of the filter over a thin aerobic biofilm. Metabolites from the biofilm are picked up and carried out with the wastewater. Trickling allows for oxygenation of the biofilm and degassing of carbon dioxide. Advantages of trickling filters include high process stability due to constant high oxygen levels; $\mathrm{CO}_{2}$ removal by degassing; water cooling in summertime; and simplicity of design, construction, operation, and management. Some disadvantages of trickling filters are the relatively low volumetric removal rates (with consequently large sized biofilters), biofilm shedding, and risk of clogging when not properly designed and operated. For certain fish species, additional solids removal is necessary (Eding and others, 2006).

Sequencing batch reactors incorporate alternating aerobic and anaerobic periods to achieve nitrification and denitrification in a single container. The aerobic phase is followed by an anaerobic phase, then a second aerobic phase, and a settling phase (Fontenot and others, 2007). Lastly, fluidized bed biofilters have a higher surface area per unit volume than other fixed film biofilters (Weaver, 2006) and can be filled with microbeads (Malone and Beecher, 2000; Timmons and others, 2006) or sand (Weaver, 2006; Davidson and others, 2008). Fluidized sand biofilters are efficient, compact, cost competitive, and relatively easy to manage (Sandu and others, 2002; Summerfelt, 2006; Weaver, 2006). Providing adequate oxygen is key to their function as about 60 percent of the dissolved oxygen used in a fluidized sand biofilter went toward nitrification (Summerfelt and Sharrer, 2004). Biofilm shearing can be done by pumping the top particles to the bottom. The released biofilm particles are less dense than the sand and simply wash out with the effluent (Davidson and others, 2008). An advantage to sand is that it has a high surface area for a relatively low cost. These biofilters can be configured to fit the space available and can treat a high volume of water with a relatively small footprint, removing 86 to 88 percent of TAN (Davidson and others, 2008). Additionally, Sandu and others (2002) found that TAN removal rate increased as column diameter increased. They also suggested that the ideal fluidized bed filter would be filled to 40-50 percent capacity with plastic medium, and upflow velocity would be 1-2 centimeters per second (cm/s) at the desired flow rate (Sandu and others, 2002). Microbead filters are a low-cost alternative to fluidized sand filters because they can be scaled to large production systems. A key advantage of microbead filters is that their cost of operation is less than a fluidized sand biofilter because of the ability to use low head high volume pumps for their operation (Timmons and others, 2006).

In a study designed to assess how three different filter types performed under production-scale tilapia culture, the floating bead and fluidized sand filters outperformed the moving bed bioreactor in terms of ammonia removal, though nitrification rates in fluidized bed biofilters were more variable. Nitrite levels were in acceptable ranges for the study duration, with the fluidized bed and moving bed bioreactor filters showing variability. The floating bead biofilter showed a net nitrite production that was attributed to capture and degradation of suspended organic solids at the bottom of the filter. This type of filter serves both as a biofilter and a mechanical filter, and captured solids are degraded between 
back washings, which were every 2 hours during the study (Guerdat and others, 2010). Another study showed that floating media used less energy to maintain flow compared to sand filters, which was seen as an advantage, particularly when both filter types had similar solids removal and turbidity reduction (Steicke and others, 2007).

Short-term shocks to biofilters, such as a change in $\mathrm{pH}$, TAN, or temperature, did not negatively affect biofilter operation, and nitrification rates returned to normal within 2 hours. Trickling filters seemed more sensitive to disturbances, perhaps because of a more immediate contact of the water on biofilm. The rate and magnitude of change may be important variables in biofilter performance, especially if change is rapid (Lyssenko and Wheaton, 2006).

Biofilms on biofilter media form layers, and movement of ammonia or nitrite into the biofilm is diffusion controlled (Rittmann and McCarty, 1980). The nitrification rate is in equilibrium between demand for ammonia or nitrite created by growth of the bacterial biomass and the rate of supply of ammonia and nitrite that can be affected by more than 20 physical, chemical, and biological factors; many of which can be optimized in RAS design. Ammonia concentration should be the primary consideration in biofilter design because ammonia is toxic to many fish species at low levels. For example, toxic levels of ammonia are 0.32 milligrams per liter $(\mathrm{mg} / \mathrm{L})$ for rainbow trout and 0.05-0.2 mg/L for other salmonids (Summerfelt and others, 2001). The highest water quality that can be maintained in RAS is defined by the minimum amount of ammonia that can sustain the nitrifier population in the biofilter. Dissolved oxygen should be maintained at $>2.3 \mathrm{mg} / \mathrm{L}$ to sustain nitrification within biofilters (Chen and others, 2006), and a DO/TAN of $>2.5$ is recommended (Chen and others, 2006; Summerfelt, 2006). Dissolved oxygen may drop rapidly in the biofilm despite sufficient dissolved oxygen in the culture water and may become the limiting factor to nitrification if it falls below $2 \mathrm{mg} / \mathrm{L}$. Turbulence can impair mass transfer into the biofilm and has the greatest effect on nutrient transfer into the biofilm. An alkalinity of $>200 \mathrm{mg} / \mathrm{L}$ is recommended to maintain optimum nitrification rates when water exchange is minimal. Alkalinity ensures adequate buffering capacity to prevent $\mathrm{pH}$ changes from the $\mathrm{H}^{+}$produced during nitrification (Chen and others, 2006). Nitrification can consume from 6.0 to 7.4 milligrams (mg) of alkalinity (as $\mathrm{CaCO}_{3}$ ) and about $4 \mathrm{mg}$ of oxygen for every $1.0 \mathrm{mg}$ of ammonia nitrogen that is converted to nitrate-nitrogen (Summerfelt and others, 2001).

Additional research on biofilters focused on use of other nitrogen oxidizing organisms and immobilizing bacteria on various substrates to help start the nitrification processes. Aspergillus niger, a fungus, was introduced into a laboratory-scale (1 liter [L]) fixed slab reactor and was found to use ammonia at low temperatures (22 degrees Celsius $\left[{ }^{\circ} \mathrm{C}\right]$ ), but switched to carbon at higher temperatures $\left(35^{\circ} \mathrm{C}\right)$. If used in a production scale biofilter, the operator would likely have to know the $\mathrm{C} / \mathrm{N}$ ratio of waste produced (Hwang and others, 2004). A similar study examined the ammonia removal rates in a continuous stirred tank reactor in a RAS. Aspergillus niger was the dominant species that removed ammonia at a daily rate of $35 \mathrm{mg}$ TAN/L. It required only 20 hours to reach a constant removal rate; however, this system also required ozone treatment (Hwang and others, 2007).

A study by Watanabe and others (2004) demonstrated that immobilized ammonia oxidizing bacteria, Nitrosomonas europaea, helped remove ammonia from rearing water. This technology may help start the nitrification process since the bacteria could be present in high amounts from the start. However, they also found that the ammonia oxidizers were damaged by light during the time the gelplate solidified (Watanabe and others, 2004). Immobilizing bacteria in a fluidized bed biofilter also was investigated as a way to increase fish resistance to disease. The bacteria Rhodopseudomonas palustris, which can inhibit and destroy reproduction of viruses, was immobilized on alginate gels covered with polyvinyl alcohol film. The resulting beads were then placed in a fluidized bed before rainbow trout or common carp (Cyprinus carpio) were added. During the study, fish growth and development was 
normal and survival rate was 98 percent. Maximum fish load was $45 \pm 3$ kilograms per cubic meter $\left(\mathrm{kg} / \mathrm{m}^{3}\right)$, ammonia nitrogen removal rate was $80-95$ percent, and nitrite $\mathrm{N}$ removal rate was $<80$ percent (Peirong and Wei, 2013).

\section{E. Bacteria That Process Nitrogen}

Two distinct groups of bacteria process nitrogen: (1) the ammonia-oxidizing bacteria of the genera Nitrosomonas, Nitrosococcus, Nitrospira, Nitrosolobus, and Nitrosovibrio; and (2) the nitriteoxidizing bacteria of the genera Nitrobacter, Nitrococcus, Nitrospira, and Nitrospina. Although growth is slow, doubling time is shorter for the ammonia-oxidizing bacteria (about 26 hours) than for nitriteoxidizing bacteria (about 60 hours). Optimal temperature for nitrification is about $25^{\circ} \mathrm{C}$, and optimal pH is 7.8 (Hagopian and Riley, 1998).

Additionally, differences are seen in bacterial populations in RAS biofilters and culture water and because each fish species introduces a unique microbiological flora, diversity varies from RAS to RAS. Diversity also is affected by use of disinfection (i.e., ozone treatments) that can affect culture water but does not affect the deeper biofilm layers. Diversity may be measured by determining the $16 \mathrm{~S}$ rRNA sequences of bacteria in the system. Ammonia oxidation is associated with Nitrosomonas sp. in freshwater systems. Nitrite and ammonia oxidation occur together in nitrification biofilters, with Nitrospira sp. being the dominant nitrite oxidizer (Schreier and others, 2010). In anaerobic areas, such as the deeper layers of the biofilm, high nitrate/nitrite levels and organic carbon wastes promote heterotrophic denitrification. Pseudomonas and Comamonas spp. are likely heterotrophs that participate in denitrification in freshwater systems (Schreier and others, 2010).

Anaerobic ammonium-oxidation or anammox bacteria in the taxon Planctomyces were discovered in the late 1990s. They convert ammonia and nitrite to nitrogen gas and water in the absence of oxygen. These bacteria are slow growing organisms (doubling times $>11$ days, Schreier and others, 2010), whose growth is inhibited by oxygen so they are likely found in the low oxygen areas of the biofilm on biofilters. The likely source of these anammox bacteria is fish feces (van Kessel and others, 2011). In a RAS culturing Scortum barcoo, the Nitrospira formed only a small part of the overall bacterial community and could not account for all the oxidation of nitrite to nitrate. It was thought that some of the Planctomycetales-related clones were participating in the ammonia removal process after the biofilter stabilized (Zhu and others, 2012). In another study, anammox-like bacteria were detected by $16 \mathrm{~S}$ rRNA analysis in a RAS containing Koi carp (Cyprinus carpio Koi) but anammox activity was not sufficient to account for significant ammonia removal (van Kessel and others, 2010).

\section{Diseases}

Bacterial, viral, fungal, and parasitic pathogens, both opportunistic and obligate, cause disease in RAS. Obligate pathogens require a host to survive and do not live long outside of the fish. The major fish pathogens include Flavobacteria, Saproeignia, Aeromonas, Vibrio, and Yersinia (Blancheton and others, 2013), and these can potentially infect fish cultured in RAS. In one study, sea bass and mullet reared in recirculation systems showed signs of infection by several bacterial species including Aeromonas ssp, Myxobacteria, and Saprolegnia. Parasites also infested the same species including Ichthyophthirius sp, Chilodonella cephalus, and Diplectanum aequans (Athanassupoulou and others, 2004). Furunculosis was found in a recirculation system growing Senegalese sole (Solea senegaleus) held at a stocking density of 25 kilograms per square meter $\left(\mathrm{kg} / \mathrm{m}^{2}\right)$ (Magariños and others, 2011). In another study, Actinomycetes were isolated from a drum filter and heat exchanger in a RAS (Schrader and Summerfelt, 2010). 
Heterotrophic bacteria are common in RAS and may cause diseases and out-compete autotrophic bacteria. They also produce significant quantities of bacterial biomass that may clog biofilters and limit nitrification (Michaud and others, 2006). Foam fractionation had variable success in removing heterotrophic bacteria (Brambilla and others, 2008).

Although it may seem that RAS would be at higher risks for disease outbreak, there were no papers found that indicated well-managed RAS had higher incidences of disease. RAS tend to be biosecure; water replacement rates are low, which may limit invasions by pathogens; and they may include a disinfection unit that reduces the risk of disease (Blancheton and others, 2013). However, if water quality is not maintained, fish may develop infections. Nile tilapia showed a higher incidence of parasitic infestation by Trichodina and monogeneans when nitrogen compounds in the RAS increased (Jiménez-García and others, 2012).

\section{Use of Formalin in RAS}

\section{A. Current U.S. Label}

Formalin is approved by the U.S. Food and Drug Administration (FDA) to treat aquatic organisms; it is an aqueous solution containing approximately 37 percent (by weight) of formaldehyde gas, United States Pharmacopeia (USP). Currently (2015; http://www.accessdata.fda.gov/scripts/animaldrugsatfda/details.cfm?dn=140-989), it is approved for the following uses:

1. control of external protozoa (Chilodonella species, Ichthyodobo species, Ichthyophthirius species, Epistylis species, Ambiphyra species, and Trichodina species) and monogenetic trematodes (Chilodonella species, Dactylogyrus species, and Gyrodactylus species) in finfish;

2. control of fungi in the family Saprolegniaceae on finfish eggs; and

3. as a parasiticide for Penaeid Sprimp.

\section{B. Application of Formalin in RAS-Effects on Biofilter Bacteria}

The literature search did not find many (five total) papers on the effects of formalin on biofilter function in RAS. From the data in the few papers that reported effects of formaldehyde on nitrification process, no appreciable effect was observed if the formaldehyde concentration was below $40 \mathrm{mg} / \mathrm{L}$. Key experimental variables are summarized in table 1.

One hour formaldehyde exposures at concentrations ranging from 50-167 parts per million (ppm) at $13.4-16.5^{\circ} \mathrm{C}$ did not affect biofilter function of a RAS that contained rainbow trout. After 17 trials, nitrite levels were elevated for 9 days, likely caused by the cumulative mortality of nitrite nitrifying bacteria. This is not a concern to RAS operators because it is very unlikely that one biofilter would be exposed to such a treatment regime. An interesting finding was that a large number of oligochaetes were shed from the biofilter at 140 and $167 \mathrm{ppm}$ formalin. Indefinite exposures, defined as no flushing of the system after application of formaldehyde, did not affect biofilter function at formalin concentrations that ranged from 15-120 ppm at culture temperatures of $16-18{ }^{\circ} \mathrm{C}$. Formaldehyde was undetectable at 11 hours after application of $120 \mathrm{ppm}$ formaldehyde, and oligochaetes were again washed from the biofilters when formaldehyde was $\geq 100 \mathrm{ppm}$. Formaldehyde was lost at a rate that was higher than that lost by water exchange, indicating a high amount of degradation within the system. Formaldehyde loss followed first order kinetics (Heinen and others, 1995). 
Keck and Blanc (2002) tested the effects of formaldehyde on biofilter bacteria in a marine recirculation system. They used two $300 \mathrm{~L}$ tanks connected to a fluidized-bed biofilter. A commercially available 33 percent formalin solution was used in treatments that ranged from 20 to $90 \mathrm{mg} / \mathrm{L}$ of formaldehyde for 2, 4, and 6 hours. Formaldehyde at these levels did not appear to inhibit ammonia oxidizers. However, at concentrations greater than $40 \mathrm{mg} / \mathrm{L}$ of formaldehyde for 1 hour, there was a significant inhibition of nitrite oxidizers. Keck and Blanc suggested that 1 hour treatments $\geq 40 \mathrm{mg} / \mathrm{L}$ formaldehyde not followed by flushing or a 4-hour or more exposure to $60 \mathrm{mg} / \mathrm{L}$ formaldehyde be considered threshold values for marine systems. Their overall conclusion was that the effect of formalin on nitrification was minimal.

Formaldehyde removal from submerged fixed biofilters was tested in a full-scale recirculation system and found to be related to available biofilter surface area. Tanks were stocked with rainbow trout (Oncorhynchus mykiss) and fed $1.6 \mathrm{~kg}$ of formulated feed daily. Daily water renewal was about 10 percent of total volume. Prior to formaldehyde application, water was turned off creating a closed circuit between the biofilter and reservoir. The biofilter contained Biobloc 150 HD ${ }^{\circledR}$ media with a total volume of 0.667 cubic meter $\left(\mathrm{m}^{3}\right)$ and a total surface area of $25 \mathrm{~m}^{2}$. A nominal concentration of 40 $\mathrm{mg} / \mathrm{L}$ formaldehyde was achieved in the tanks, and this was allowed to pass through the biofilter. Formaldehyde was eliminated in 32 to 35 hours at $15{ }^{\circ} \mathrm{C}$, and 60 hours at $10^{\circ} \mathrm{C}$, which approximated zero order kinetics. In a similar pilot-scale study, zero order elimination also was observed. In the fullscale experiment, a 13 percent increase in removal was found for every $1{ }^{\circ} \mathrm{C}$ increase, resulting in a $\mathrm{Q}_{10}$ (the change in rate of the measured variable that results when temperature is increased by $10^{\circ} \mathrm{C}$ ) of 3.4 in the temperature range of 5.7 to $16.2^{\circ} \mathrm{C}$. No appreciable changes to biofilter function were observed (Pedersen and others, 2007).

Breakdown of formaldehyde in a RAS with a trickling filter increased as temperature of the system increased (Pedersen and Pedersen, 2006). The estimated half-life of formaldehyde at $5.5^{\circ} \mathrm{C}$ was 16 hours, but only 5 hours at $14.5^{\circ} \mathrm{C}$. The results of the study by Pedersen and Pedersen (2006) indicate that trickling filters can help remove formaldehyde and that bacterial decomposition played a large role in formaldehyde decomposition.

Repetitive longer term static applications of formalin in a pilot-scale test of a freshwater RAS holding rainbow trout also were investigated. Specifically, the authors tested the effects of formalin on submerged upflow biofilter function and fish growth. The biofilters contained Biobloc $150 \mathrm{HD}{ }^{\circledR}$ media with a total volume of $0.166 \mathrm{~m}^{3}$ and a total surface area of $25 \mathrm{~m}^{2}$. The treatment tanks received 10$20 \mathrm{mg} / \mathrm{L}$ formaldehyde either daily or weekly, and formaldehyde removal was monitored for 10 weeks. When low formalin levels were used daily, formaldehyde removal increased and nitrogen removal from the RAS was not affected. At intermittent doses, variability was seen in ammonia and nitrate oxidation. Overall abundance of ammonia-oxidizing and nitrogen-oxidizing bacteria was higher in the untreated tanks. Prolonged additions of low dose formalin resulted in increased removal of formaldehyde without affecting biofilter performance. Fish growth was not affected by the formalin treatments. One drawback to repeated treatments with formalin is protozoan resistance (Pedersen and others, 2010). 
Table 1. Summary of papers that tested the effects of formaldehyde on recirculating aquaculture systems. $\left[\mathrm{kg} / \mathrm{m}^{3}\right.$, kilogram per cubic meter; ${ }^{\circ} \mathrm{C}$, degrees Celsius; mg/L, milligrams per liter; NR, not reported by authors]

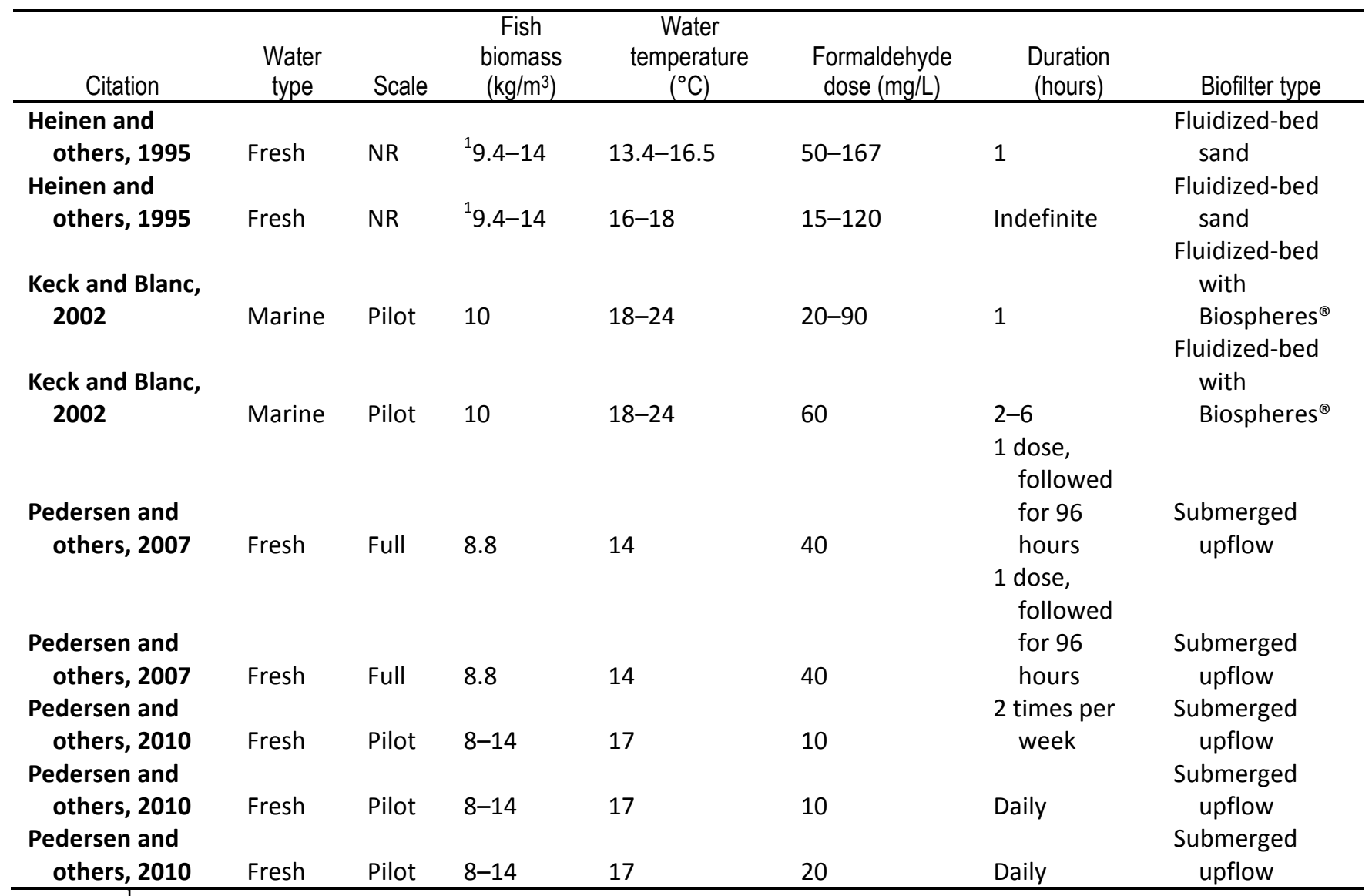

${ }^{1}$ Fish biomass had to be estimated because only the entire biomass range was reported. The estimate was made by dividing range of biomass provided by number of trials, then by the reported tank volume of 10 cubic meters.

\section{Conclusions}

- The maximal level of formaldehyde that would not impair biofilter function was $40 \mathrm{mg} / \mathrm{L}$ or less.

- Although minor alterations in the microbial abundance of ammonia-oxidizing and nitriteoxidizing bacteria occurred, repeated dosing of biofilters at low formaldehyde levels (10-20 mg/L or less) appeared to be safe and had no major adverse effects on biofilter function.

- If a particular biofilter is repeatedly exposed to low levels of formaldehyde over the course of several weeks, the nitrite nitrifying bacteria could be inhibited.

\section{References Cited}

Al-Hafedh, Y.S., Alam, Aftab, Alam, M.A., 2003, Performance of plastic biofilter media with different configuration in a water recirculation system for the culture of Nile tilapia (Oreochromis niloticus): Aquacultural Engineering, v. 29, nos. 3-4, p. 139-154. 
Athanassopoulou, F., Billinis, C., and Prapas, T., 2004, Important disease conditions of newly cultured species in intensive freshwater farms in Greece-First incidence of nodavirus infection in Acipenser sp.: Diseases of Aquatic Organisms, v. 60, p. 247-252.

Auffret, Marc; Yergeau, Étienne; Pilote, Alexandre; Proulx, Émilie; Proulx, Daniel; Geer, C.W.; Vandenberg, Grant; and Villemur, Richard, 2013, Impact of water quality on the bacterial populations and off-flavours in recirculating aquaculture systems: FEMS Microbiology Ecology, v. 84, no. 2, p. 235-247.

Avnimelech, Yoram, 2006, Bio-filters-The need for a new comprehensive approach: Aquacultural Engineering, v. 34, p. 172-178.

Badiola, Maddi; Mendiola, Diego; and Bostock, John, 2012, Recirculating Aquaculture Systems (RAS) analysis-Main issues on management and future challenges: Aquacultural Engineering, v. 51, p. 26-35.

Barbu, Marian, 2012, Experimental results regarding the operating regimes of trickling filters in recirculating aquaculture systems: Fresenius Environmental Bulletin, v. 21, no. 11C, p. 3500-3506.

Barbu, Marian; Caraman, Sergiu; and Ceangă, Emil, 2008, A modified ASM3 model for a trickling filter: Roumanian Biotechnological Letters, v. 13, p. 39-48.

Blancheton, J.P., Attramadal, K.J., Michaud, L., d’Orbcastel, E.R., and Vadstein, O., 2013, Insight into bacterial population in aquaculture systems and its implication: Aquacultural Engineering, v. 53, p. 30-39.

Brambilla, Fabio; Antonini, Micaela; Ceccuzzi, Pietro; Terova, Genciana; and Saroglia, Marco, 2008, Foam fractionation efficiency in particulate matter and heterotrophic bacteria removal from a recirculating sea bass (Dicentrarchus labrax) system: Aquacultural Engineering, v. 39, p. 37-42.

Bravo, S., Nuñez, M., and Silva, M.T., 2013, Efficacy of the treatments used for the control of Caligus rogercresseyi infecting Atlantic salmon, Salmo salar L., in a new fish-farming location in Region XI, Chile: Journal of Fish Diseases, v. 36, no. 3, p. 221-228.

Brazil, B.L., 2006, Performance and operation of a rotating biological contactor in a tilapia recirculating aquaculture system: Aquacultural Engineering, v. 34, no. 3, p. 261-274.

Cabello, Felipe, 2006, Heavy use of prophylactic antibiotics in aquaculture: a growing problem for human and animal health and for the environment: Environmental Microbiology, v. 8, p. 1137-1144.

Cabello, Felipe; Godfrey, H.P.; Tomova, Alexandra; Ivanova, Larisa; Dölz, Humberto; Millanao, Ana; and Buschmann, A.H., 2013, Antimicrobial use in aquaculture re-examined-Its relevance to antimicrobial resistance and to animal and human health: Environmental Microbiology, v. 15, p. 1917-1942.

Cancino-Madariaga, Beatriz, Hurtado, C.F., and Ruby, Rene, 2011, Effect of pressure and pH in ammonium retention for nanofiltration and reverse osmosis membranes to be used in recirculating aquaculture systems (RAS): Aquacultural Engineering, v. 45, p. 103-108.

Caraman, S., Barbu, M., Ionescu, T., Ifrim, G., Cristea, V., and Ceangă, E., 2010, The analysis of dynamic properties of the wastewater treatment process in a recirculating aquaculture system:

Romanian Biotechnological Letters, v. 15, p. 5457-5466.

Carrera, L., Cota, N., Montes, M., Mateo, E., Sierralta, V., Castro, T., Perea, A., Santos, C., Catcoparco, C., and Espinoza, C., 2013, Broodstock management of the fine flounder Paralichthys adspersus (Steindachner, 1867) using recirculating aquaculture systems: Latin America Journal of Aquatic Research, v. 41, p. 89-98.

Chen, S., Ling, J., and Blancheton, J.P., 2006, Nitrification kinetics of biofilm as affected by water quality factors: Aquacultural Engineering, v. 34, p. 179-197. 
Colt, J., Lamourex, J., Patterson, R., and Rogers, G., 2006, Reporting standards for biofilter performance: Aquacultural Engineering, v. 34, p. 377-388.

Crab, Roselien; Avnimelech, Yoram; Defoirdt, Tom; Bossier, Peter; and Verstraete, Willy, 2007, Nitrogen removal techniques in aquaculture for a sustainable production: Aquaculture, v. 207, p. 1-14.

Davidson, John; Helwig, Neil; and Summerfelt, S.T., 2008, Fluidized sand biofilters used to remove ammonia, biochemical oxygen demand, total coliform bacteria, and suspended solids from an intensive aquaculture effluent: Aquacultural Engineering, v. 39, p. 6-15.

De Schryver, Peter, and Verstraete, Willy, 2009, Nitrogen removal from aquaculture pond water by heterotrophic nitrogen assimilation in lab-scale sequencing batch reactors: Bioresource Technology, v. 100, p. 1162-1167.

d'Orbcastel, E.R., Blancheton, Jean-Paul, and Belaud, Alain, 2009a, Water quality and rainbow trout performance in a Danish Model Farm recirculating system-Comparison with flow through system: Aquacultural Engineering, v. 40, p. 135-143.

d'Orbcastel, E.R., Blancheton, Jean-Paul, and Aubin, Joël, 2009b, Towards environmentally sustainable aquaculture-Comparison between two trout farming systems using Life Cycle Assessment: Aquacultural Engineering, v. 40, p. 113-119.

Droppo, I.G.; Jaskot, Chris; Nelson, Tara; Milne, Jacqui; and Charlton, Murray, 2007, Aquaculture waste sediment stability-Implications for waste migration: Water Air Soil Pollution, v. 183, p. 59-68.

Ebeling, J.M., Timmons, M.B., and Bisogni, J.J., 2006, Engineering analysis of the stoichiometry of photoautotrophic, autotrophic, and heterotrophic removal of ammonia-nitrogen in aquaculture systems: Aquaculture, v. 257, p. 346-358.

Eding, E.H., Kamstra, A., Verreth, J.A., Huisman, E.A., and Klapwikj, A., 2006, Design and operation of nitrifying trickling filters in recirculating aquaculture-A review: Aquacultural Engineering, v. 34, p. 234-260.

Fontenot, Q., Bonvillain, C., Kilgen, M., and Boopathy, R., 2007, Effects of temperature, salinity, and carbon-Nitrogen ratio on sequencing batch reactor treating shrimp aquaculture wastewater: Bioresource Technology, v. 98, p. 1700-1703.

Food and Agriculture Organization of the United Nations, 2014, The State of World Fisheries and Aquaculture-Opportunities and challenges: Rome, 223 p., accessed February 13, 2015, at http://www.thefishsite.com/articles/1888/the-state-of-world-fisheries-and-aquaculture-2014.

Gendel, Youri, and Lahav, Ori, 2013, A novel approach for ammonia removal from fresh-water recirculated aquaculture systems, comprising ion exchange and electrochemical regeneration: Aquacultural Engineering, v. 52, p. 27-38.

Ghaly, A.E., Kamal, M., and Mahmoud. N.S., 2005, Phytoremediation of aquaculture wastewater for water recycling and production in fish feed: Environment International, v. 31, p. 1-13.

Good, C., Davidson, J., Welsh, C., Brazil, B., Snekvik, K., and Summerfelt. S., 2009, The impact of water exchange rate on the health and performance of rainbow trout Oncorhynchus mykiss in water recirculation aquaculture systems: Aquaculture, v. 294, p. 80-85.

Grave, Kari; Lingaas, Egil; Bangen, Marit; and Rønning, Marit, 1999, Surveillance of the overall consumption of antibacterial drugs in humans, domestic animals and farmed fish in Norway in 1992 and 1996: Journal of Antimicrobial Chemotherapy, v. 43, p. 243-252.

Gross, Amit; Nemirovsky, Anna; Zilberg, Dina; Khaimov, Anna; Brenner, Asher; Snir, Eviatar; Ronen, Zeev; and Nejidat, Ali, 2003, Soil nitrifying enrichments as biofilter starters in intensive recirculating saline water aquaculture: Aquaculture, v. 223, p. 51-62. 
Guerdat, T.C., Losordo, T.M., Classen, J.J., Osborne, J.A., and DeLong, D.P., 2010, An evaluation of commercially available biological filters for recirculating aquaculture systems: Aquacultural Engineering, v. 42, no. 1, p. 38-49.

Guerdat, T.C., Losordo, T.M., Classen, J.J., Osborne, J.A., and DeLong, Dennis, 2011, Evaluating the effects of organic carbon on biological filtration performance in a large scale recirculating aquaculture system: Aquacultural Engineering, v. 44, no. 1, p. 10-18.

Gullian-Klanian, M., and Arámburu-Adame, C., 2013, Performance of Nile tilapia Oreochromis niloticus fingerlings in a hyper-intensive recirculating aquaculture system with a low water exchange: Latin American Journal of Aquatic Research, v. 41, p. 150-162.

Gutierrez-Wing, M.T., and Malone, R.F., 2006, Biological filters in aquaculture-Trends and research directions for freshwater and marine applications: Aquacultural Engineering, v. 34, p. 163-171.

Guttman, Lior, and van Rijn, Jaap, 2008, Identification of conditions underlying production of geosmin and 2-methylisoborneol in a recirculation system: Aquaculture, v. 279, p. 85-91.

Hagopian, D.S., and Riley, J.G., 1998, A closer look at the bacteriology of nitrification: Aquacultural Engineering, v. 18, p. 223-244.

Håstein, T., Hjeltnes, B., Lillehaug, A., Skåre, J.U., Berntssen, M., and Lundebye, A.K., 2006, Food safety hazards that occur during the production stage-Challenges for fish farming and the fishing industry: Revue Scientifique et Technique (International Office of Epizootics), v. 25, no. 2, p. 607-625.

Heinen, J.M., Weber, A.L., Noble, A.C., and Morton, J.D., 1995, Tolerance to formalin by a fluidizedbed biofilter and rainbow trout Oncorhynchus mykiss in a recirculating culture system: Journal of the World Aquaculture Society, v. 26, no. 1, p. 65-71.

Heuer, O.E., Kruse, Hilde, Grave, Kari, Collignon, P., Karunasagar, Iddya, and Angulo, F.J., 2009, Human health consequences of use of antimicrobial agents in aquaculture: Clinical Infectious Diseases, v. 49, p. 1248-1253.

Hussenot, J.M., 2003, Emerging effluent management strategies in marine fish-culture farms located in European coastal wetlands: Aquaculture, v. 226, nos. 1-4, p. 113-128.

Hwang, S.C., Lin, C.S., Chen, I.M., Chen, J.M., Liu, L.Y., and Dodds, W.K., 2004, Removal of multiple nitrogenous wastes by Aspergillus niger in a continuous fixed-slab reactor: Bioresource Technology, v. 93, no. 2, p. 131-138.

Hwang, S.C., Lin, C.S., Chen, I.M., and Wu, J.S., 2007, Removal of nitrogenous substances by Aspergillus niger in a continuous stirred tank reactor (CSTR) system: Aquacultural Engineering, v. 36, no. 2, p. 177-183.

Jacobs, Anelet, and Chenia, H.Y., 2011, Biofilm formation and adherence characteristics of an Elizabethkingia meningoseptica isolate from Oreochromis mossambicus: Annals of Clinical Microbiology and Antimircobials, v. 10, p. 16.

Jiménez-García, Isabel, Rojas-García, C.R., Castro-José, C.N., Pavón-Suriano, Salim, Lango-Reynoso, Fabiola, and Castañeda-Chávez, M.D.R., 2012, Growth enhancement, survival and decrease of ectoparasitic infections in masculinized Nile tilapia fry in a recirculating aquaculture system: Tropical and Subtropical Agroecosystems, v. 15, p. S51-S56.

Kamstra, A., van der Heul, J.W., and Nijhof, M., 1998, Performance and optimisation of trickling filters on eel farms: Aquacultural Engineering, v. 17, no. 3, p. 175-192.

Keck, Nicolas, and Blanc, Guillaume, 2002, Effects of formalin chemotherapeutic treatments on biofilter efficiency in a marine recirculating fish farming system: Aquatic Living Resources, v. 15, no. 6, p. 361-370. 
King, R.K., Flick, G.J., Jr., Smith, S.A., Pierson, M.D., Boardman, G.D., and Coale, C.W., Jr., 2008, Response of bacterial biofilms in recirculating aquaculture systems to various sanitizers: Journal of Applied Aquaculture, v. 20, no. 2, p. 79-92.

Kuhn, D.D., Drahos, D.D., Marsh, Lori, and Flick, G.J., Jr., 2010, Evaluation of nitrifying bacteria product to improve nitrification efficacy in recirculating aquaculture systems: Aquacultural Engineering, v. 43, no. 2, p. 78-82.

Luo, Guo-zhi; Avnimelech, Yoram; Pan, Yun-feng; and Tan, Hong-xin, 2013, Inorganic nitrogen dynamics in sequencing batch reactors using biofloc technology to treat aquaculture sludge: Aquacultural Engineering, v. 52, p. 73-79.

Lyssenko, Catherine, and Wheaton, Fred, 2006, Impact of rapid impulse operating disturbances on ammonia removal by trickling and submerged-upflow biofilters for intensive recirculating aquaculture: Aquacultural Engineering, v. 35, no. 1, p. 38-50.

Magariños, B., Devesa, S., González, A., Castro, N., and Toranzo, A.E., 2011, Furunculosis in Senegalese sole (Solea senegalensis) cultured in a recirculation system: Veterinary Record, v. 168, no. 16, p. 431-433.

Malone, R.F., and Beecher, L.E., 2000, Use of floating bead filters to recondition recirculating waters in warmwater aquaculture production systems: Aquacultural Engineering, v. 22, nos. 1-2, p. 57-73.

Malone, R.F., and Pfeiffer, T.J., 2006, Rating fixed film nitrifying biofilters used in recirculating aquaculture systems: Aquacultural Engineering, v. 34, no. 3, p. 389-402.

Marin, P., Donoso-Bravo, A., Campos, J.L., Ruiz-Filippi, G., and Chamy, R., 2011, Performance of an in-situ rotating biological contactor in a recirculating aquacultural system: Water Science and Technology, v. 64, no. 11, p. 2217-2222.

Michaud, L. Blancheton, J.P., Bruni, V., and Piedrahita, R., 2006, Effect of particulate organic carbon on heterotrophic bacterial populations and nitrification efficiency in biological filters: Aquacultural Engineering, v. 34, no. 3, p. 224-233.

Ogunlela, A.O, and Ogunlana, A.S., 2011, Application of lava stones and oyster shells as biofilter substrates in a recirculatory aquaculture system: Journal of Applied Sciences Research, v. 7, no. 2, p. 88-90.

Panigrahi, A., and Azad, I.S., 2007, Microbial intervention for better fish health in aquaculture-The Indian scenario: Fish Physiology and Biochemistry, v. 33, no. 4, p. 429-440.

Park, Jeonghwan, Kim, H.B., Kim, P.K., and Jo, J.Y., 2008, The growth of disk abalone, Haliotis discus hannai at different culture densities in a pilot-scale recirculating aquaculture system with a baffled culture tank: Aquacultural Engineering, v. 38, no. 3, p. 161-170.

Pedersen, Lars-Flemming, Pedersen, Per Bovbjerg, 2006, Temperature-dependent formaldehyde degradation in trickling filters: North American Journal of Aquaculture, v. 68, no. 3, p. 230-234.

Pedersen, Lars-Flemming, and Pedersen, P.B., Nielsen, J.L., and Nielsen, P.H., 2009, Peracetic acid degradation and effects on nitrification in recirculating aquaculture systems: Aquaculture, v. 296, nos. 3-4, p. 246-254.

Pedersen, Lars-Flemming, Pedersen, P.B., Nielsen, J.L., and Nielsen, P.H., 2010, Long term/low dose formalin exposure to small-scale recirculation aquaculture systems: Aquacultural Engineering, v. 42, no. 1, p. 1-7.

Pedersen, Lars-Flemming, Pedersen, P.B., and Sortkjaer, Ole, 2007, Temperature-dependent and surface specific formaldehyde degradation in submerged biofilters: Aquacultural Engineering, v. 36, no. 2, p. 127-136. 
Peirong, Zhan, and Wei, Liu, 2013, Use of fluidized bed biofilter and immobilized Rhodopseudomonas palustris for ammonia removal and fish health maintenance in a recirculation aquaculture system: Aquaculture Research, v. 44, no. 3, p. 327-334.

Peng, Lei; Oh, Sung-Yong; and Jo, Jae-Yoon, 2003, Organic matter and hydraulic loading effects on nitrification performance in fixed film biofilters with different filter media: Ocean and Polar Research, v. 25, no. 3, p. 277-286.

Pfeiffer, T.J., and Wills, P.S., 2011, Evaluation of three types of structured floating plastic media in moving bed biofilters for total ammonia nitrogen removal in a low salinity hatchery recirculating aquaculture system: Aquacultural Engineering, v. 45, no. 2, p. 51-59.

Porrello, Salvatore; Lenzi, Mauro; Tomassetti, Paolo; Persia, Emma; Finoia, M.G.; and Mercatali, Isabel, 2003, Reduction of aquaculture wastewater eutrophication by phytotreatment ponds systemII. Nitrogen and phosphorus content in macroalgae and sediment: Aquaculture, v. 219, nos. 1-4, p. 531-544.

Prinsloo, J.F., Roets, W., Theron, J., Hoffman, L.C., and Schoonbee, H.J., 1999, Changes in some water quality conditions in recycling water using three types of biofiltration systems during the production of sharptooth catfish Clarias gariepinus (Burchell) - Part I. Relative efficiency in the breakdown of nitrogenous wastes by the different biofiltration units: Water SA, v. 25, no. 2, p. 239-252.

Rittmann, B.E., and McCarty, P.L., 1980, Model of steady-state-biofilm kinetics: Biotchnology and Bioengineering, v. 22, no. 11, p. 2343-2357.

Saliling, W.J., Westerman, P.W., and Losordo T.M., 2007, Wood chips and wheat straw as alternative biofilter media for denitrification reactors treating aquaculture and other wastewaters with high nitrate concentrations: Aquacultural Engineering, v. 37, no. 3, p. 222-233.

Sandu, S.I., Boardman, G.D., Watten, B.J., and Brazil, B.L., 2002, Factors influencing the nitrification efficiency of fluidized bed filter with a plastic bead medium: Aquacultural Engineering, v. 26, no. 1, p. 41-59.

Schrader, K.K., and Summerfelt, S.T., 2010, Distribution of off-flavor compounds and isolation of geosmin-producing bacteria in a series of water recirculating systems for rainbow trout culture: North American Journal of Aquaculture, v. 72, p. 1-9.

Schramm, A., Larsen, L.H., Revsbech, N.P., Ramsing, N.B., Amann, R., and Schleifer, K.H., 1996, Structure and function of a nitrifying biofilm as determined by in situ hybridization and the use of microelectrodes: Applied and Environmental Microbiology, v. 62, no. 12, p. 4641-4647.

Schreier, H.J., Mirzoyan, Natella, and Saito, Keiko, 2010, Microbial diversity of biological filters in recirculating aquaculture systems: Current Opinion in Biotechnology, v. 21, no. 3, p. 318-325.

Singh, Sahdev, and Marsh, L.S., 1996, Modelling thermal environment of a recirculating aquaculture facility: Aquaculture, v. 139, nos. 1-2, p. 11-18.

Skjølstrup, J., Nielsen, P.H., Frier, J.-O., and McLean, E., 1998, Performance characteristics of fluidised bed biofilters in a novel laboratory-scale recirculation system for rainbow trout-Nitrification rates, oxygen consumption and sludge collection: Aquacultural Engineering, v. 18, no. 4, p. 265-276.

Steicke, C., Jegatheesan, V., and Zeng, C., 2007, Mechanical mode floating medium filters for recirculating systems in aquaculture for higher solids retention and lower freshwater usage: Bioresource Technology, v. 98, no. 17, p. 3375-3383.

Summerfelt, S.T., 2006, Design and management of conventional fluidized-sand biofilters: Aquacultural Engineering, v. 34, no. 3, p. 275-302.

Summerfelt, S., Bebak-Williams, J., and Tsukuda, S., 2001, Controlled systems-Water reuse and recirculation, in Wedemeyer, G.A., ed., Fish Hatchery Management: Bethesda, Md., American Fisheries Society, p. 285-395. 
Summerfelt, S.T., and Sharrer, M.J., 2004, Design implication of carbon dioxide production within biofilters contained in recirculating salmonid culture systems: Aquacultural Engineering, v. 32, no. 1, p. 171-182.

Suzuki, Yoshihiro; Maruyama, Toshiroh; Numata, Hiroyuki; Sato, Hajime; and Asakawa, Makio, 2003, Performance of a closed recirculating system with foam separation, nitrification, and denitrification units for intensive culture of eel—Towards zero emission: Aqaucultural Engineering, v. 29, p. 165-182.

Svododová, Z., Máchová, J., Poleszczuk, G., Hůda, J., Hamáčková, J., and Kroupová, H., 2005, Nitrite poisoning of fish in aquaculture facilities with water-recirculating systems: Acta Veterinaria Brno, v. 74, no. 1, p. 129-137.

Timmons, M.B., Holder, J.L., and Ebeling, J.M., 2006, Application of microbead biological filters: Aquacultural Engineering, v. 34, p. 332-343.

van Kessel, M.A., Harhangi, H.R., Flik, Gert, Jetten, M.S., Klaren, P.H., and Op den Camp, H.J., 2011, Anammox bacteria in different compartments of recirculating aquaculture systems: Biochemical Society Transactions, v. 39, no. 6, p. 1817-1821.

van Kessel, M.A., Harhangi, H.R., van de Pas-Schoonen, Katinka, van de Vossenberg, Jack, Flik, Gert, Jetten, M.S., Klaren, P.H., and Op den Camp, H.J., 2010, Biodiverisy of N-cycle bacteria in nitrogen removing moving bed biofilters for freshwater recirculating aquaculture systems: Aquaculture, v. 306, nos. 1-4, p. 177-184.

Watanabe, Atsushi; Uemoto, Hiroaki; Morisa, Masahiko; Saito, Shin; and Yoshizaki, Rika, 2004, Development of nitrogen-removal bioreactor using poly(lactic acid) as an energy source: Biological Sciences in Space, v. 18, no. 3, p. 142-143.

Weaver, D.E., 2006, Design and operations of fine media fluidized bed biofilters for meeting oliotrophic water requirements: Aquacultural Engineering, v. 34, p. 303-310.

Wik, Torsten, Björn, E.I., Lindén, T., and Wramner, P.I., 2009, Integrated dynamic aquaculture and wastewater treatment modeling for recirculating aquaculture systems: Aquaculture, v. 287, p. 361-370.

Yang, Lei; Chou, Lin-Sen; and Shieh, Wen, 2001, Biofilter treatment of aquaculture water for reuse applications: Water Research, v. 35, p. 3097-3108.

Zhu, Peng; Ye, Yangfang; Pei, Fangfang; and Lu, Kaihong, 2012, Characterizing the structural diversity of a bacterial community associated with filter materials in recirculating aquaculture systems of Scortum barcoo: Canadian Journal of Microbiology, v. 58, p. 303-312.

Zhu, S., and Chen, S., 2001, Effects of organic carbon on nitrification rate in fixed film biofilters: Aquacultural Engineering, v. 25, p. 1-11. 
ISSN 2331-1258 (online)

http://dx.doi.org/10.3133/ofr20151097 